\title{
Sustainable Value Creation in Latvia, Lithuania and Estonia: Comparative Analysis of Economic Return from the Use of Economic, Social and Environmental Resources
}

\author{
Jeḷena Lonska \\ Rezekne Academy of Technologies
}

\begin{abstract}
Baltic neighbouring countries Latvia, Lithuania and Estonia all over the world are considered as brotherly nations that have similar historical events and political economic system. However, for the period of 25 years after gaining their independence from the Soviet Union in 1990, these countries have been implementing different socio-economic development models. It can be concluded on the achieved development results by the world recognized and widely used index indicators as Human Development Index (HDI), Global Competitiveness Index (GCI), Doing Business Index (DBI), revealing a trend that Estonia according to the socio-economic indicators is a step ahead of both Latvia and Lithuania. However, the above-mentioned indices calculation does not include the environmental indicators (HDI report includes Environmental Sustainability subindex, which is calculated separately) that cannot take account of national sustainable development which is becoming increasingly important under the conditions of global resource scarcity. The aim of the research is to determine sustainability of Latvia, Lithuania and Estonia, using the Sustainable Value (SV) approach, calculating how efficiently and with what return (Country's Gross Domestic Product) their economic, social and environmental resources are consumed. $S V$ is a value-based assessment that measures contributions to sustainability in monetary terms while being able to use non-monetary environmental and social input variables. Calculating SV of Latvia, Lithuania and Estonia, the author has used 10 indicators of 2014 that cover the economic, social and environmental dimensions of sustainability, using the average efficiency of these countries as benchmark. As a result the author concluded that, overall, Latvia and Lithuania have almost equal footing with the Return to Cost Ratio (RCR) results, respectively 1.41 and 1.32 (>1 means that resources are used more efficiently than the benchmark), while Estonia's RCR value is 0.52 ( $<1$ means that resources are used less efficiently than the benchmark), which can be explained by differences in national economic structure and the energy independence. The study also showed that there are substantial differences among the countries in economic return from each individual resource use.
\end{abstract}

Keywords: sustainable development, Sustainable Value, Gross Domestic Product, Latvia, Lithuania, Estonia.

\section{INTRODUCTION}

In 1990, after regaining the independence from the Soviet Union, Latvia, Lithuania and Estonia faced big challenges in terms of both the economic transition from centrally planned economic to a market economy model as well as the political stability, providing necessary resources for existence and functioning of the countries. For 25 years these countries were implementing different development models. We can evaluate their achievements of the development by the world recognized and widely used index of indicators, for example, according to the HDI in 2015, Estonia rates in the 30th place in the world, Lithuania - 37, Latvia - 46 [1], according to the GCI in the period of the year 2016/2017, Estonia ranks in the 30th place in the world, Lithuania - 35, Latvia - 49 [2], according to the DBI in 2017, Estonia ranks in the 12 th place in the world, Latvia - 14 ,
Lithuania - 21 [3]. According to socio-economic indicators, it is evident that Estonia is ahead both Latvia and Lithuania. However, the environmental indicators are not included in the above-mentioned index calculation, which means that when analyzing these indices, we can't evaluate the sustainability of the countries, importance of which is increasing due to the global resource scarcity.

The aim of the research is to provide the analysis of the sustainability performance of Latvia, Lithuania and Estonia in 2014 in monetary terms using the Sustainable Value $[4,5]$. Sustainable Value combines economic return with the use of economic, environmental and social burdens and therefore relates the challenge of economic growth to the challenges of environmental and social stewardship. All other existing assessment approaches are burdenbased. Sustainable Value is based on the assumption

ISSN 1691-5402

(C) Rezekne Academy of Technologies, Rezekne 2017 http://dx.doi.org/ 10.17770/etr2017voll.2628 
that value is created when a resource is used more efficiently than by an alternative use [6].

In 1972 members of the Club of Rome - a group of thinkers in politics, business and science published disturbing scenarios suggesting that unbounded growth of population, pollution and depletion of natural resources would cause the collapse of physical growth on Earth [7].

Nowadays there are a number of researches implemented in economic science and its interdisciplinary sciences, such as environmental economics, green economics, ecological economics, bio-economics and in other environmental social sciences, proving that the economic growth leaves a negative impact on the environment $[8,9,10,11,12$, 13].

The implications of global warming and environmental despoliation have increased the clamor for sustainable development - economic development that seeks to meet current needs without compromising the ability to meet future needs [14].

In 1987 the World Commission on Environment and Development issued an influential report, Our Common Future (the Brundtland Report), which stressed the interdependence of ecological and economic systems, and made a strong plea for the principles of sustainable development. According to the definition by Brundtland Commission (1987), the sustainable development is a "development that meets the needs of the present without compromising the ability of future generations to meet their own needs" [15].

In 2015 the United Nations General Assembly adopted the 2030 Agenda for Sustainable Development and 17 Sustainable Development Goals as a universal and transformative development strategy. The 2030 Agenda commits the global community to "achieving sustainable development in its three dimensions - economic, social and environmental - in a balanced and integrated manner" [16]. The interaction of the economic, social and environmental dimensions and their relevance to sustainable development is shown in the Figure 1.

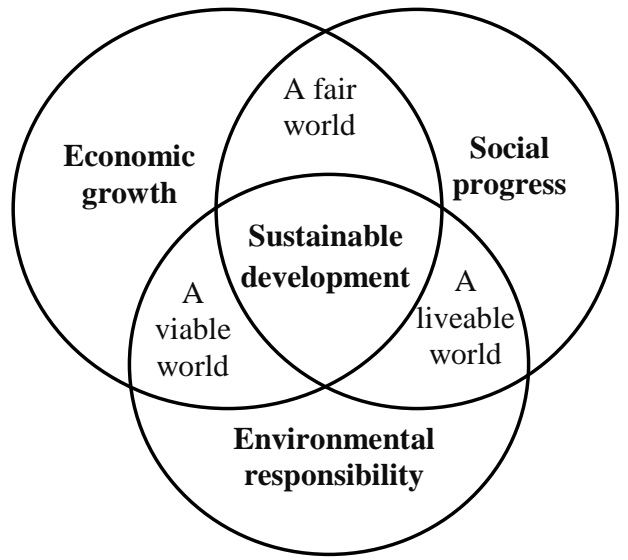

Fig. 1. Standard dimensions of sustainable development [17]
After analysing the Figure1, it can be concluded that in order to achieve sustainable development, it is crucial to harmonize three core sustainable development's elements: economic growth, social progress and environmental responsibility. These elements are interconnected and all are crucial for the well-being of individuals and societies in fair, liveable and viable world.

The relationship between economic growth and the sustainable development is complex. Economic growth involves the combination of different types of capital to produce goods and services. The maintenance of all types of capital is essential for the sustainability of economic growth. The most known capitals are identified by the "Forum for the Future", i.e. manufactured, financial, social, human and natural capital (see Figure 2).

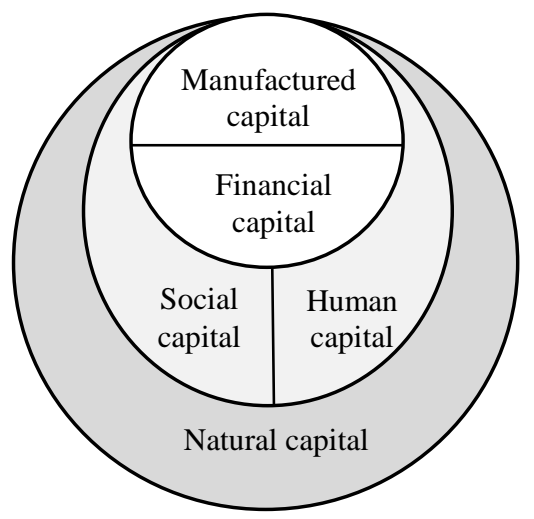

Fig. 2. The five capitals model [18]

The five capitals model of sustainable development was developed by "Forum for the Future" in the 1990's. The model is used to show stocks and flows of resources as they relate to a sustainable society and economy. The purpose of this model is to illustrate the interconnectedness of various types of capital and the dynamic process through which organizations around the world can begin to achieve a balance between their environmental, social and economic needs [18, 19].

Most views of sustainability are concerned with the resource stock left for future generations. Goodwin (2003) suggests that for sustainability, the total stock of the five capitals should be maintained although the depletion of one type can be compensated for by the increase in others [19].

In nowadays, in the century of high-tech, economic growth can avoid the environmental pollution and over- consumption of the resources; especially this can be implemented in the countries with high incomes. It is facilitated by the composition effect, when the economic structure changes from secondary (or manufacturing) sector to tertiary (or service) sector, and the technical effect, when technological development and investment in the infrastructure can make the burden on the environment less, nevertheless in both cases the key 
role is allotted to a stronger environmental policy [20, 21, 22, 23].

It is possible to calculate how efficiently and with what return economic, social and environmental resources of the country (or industry) are consumed, providing the country's (or company's) economic growth. The Sustainable Value approach is used for the purpose to measure the country's (or company's) sustainability performance $[4,5]$.

\section{MATERIALS AND METHODS}

The Sustainable Value (SV) approach was developed by Figge and Hahn [4, 5] and used both widely on a corporate level [24, 25], as well as on a macro level [6, 26, 27]. SV uses the return that is created with a resource as the basis for sustainability assessment.

SV approach advantage is that it measures contributions to sustainability in monetary terms, taking into account economic, social and environment dimensions of sustainability, while being able to use nonmonetary environmental and social input variables. SV shows the value that is created or lost through the use of a set of different resources by a country (or company). SV is based on a fundamental insight of financial economics: to create value, a country (or company) must use resources more efficiently than other countries (or companies). SV can take into account all kinds of resources as long as they are necessary for production, scarce and can be measured in absolute quantitative terms. In practice the choice of indicators is limited by availability $[27,28]$.

SV shows how much more return was created by giving a set of resources to the country (or company) rather than to the benchmark. SV does not claim that the benchmark is sustainable. Instead SV expresses in monetary terms the degree of sustainability relative to this benchmark. If the benchmark consists of future target efficiency, SV shows how well companies or countries perform today relative to this desired state. In the financial markets it is often argued that opportunity cost thinking in a market economy will drive up the efficiency of resource use, which is socially desirable. A more efficient use of a resource is linked to more value creation. To create positive SV a resource must earn its opportunity cost, i.e. it must at least match the return of an alternative use. If a country (or company) creates SV does not only depend on the efficiency of the country (or company) but also on the benchmark that is chosen. SV shows which resources are used in a value-creating way and which are not. SV does not take into account qualitative aspects of sustainability which cannot be quantified in a meaningful way [27, 28].

Five questions help to define the individual SV application [28]:

(1) Which object? This first decision question covers what the assessment objects are, i.e. what is being assessed. In this research these are 3 countries of the Baltic Sea region, i.e. Latvia, Lithuania and Estonia.

(2) Which benchmark? SV is created when the assessment object, as defined in the previous step, earns its opportunity cost, i.e. has a higher efficiency than the benchmark. This decision defines the benchmark that the assessment objects are compared to. In this research the average efficiency of Latvia, Lithuania and Estonia as the benchmark was applied.

(3) Which resources? The SV approach can cover economic, environmental and social resources. The present study considers enterprises' assets, liabilities and equity (total EUR, at the end of the year) [29, 30, 31] as economic resources; carbon dioxide $\mathrm{CO}_{2}$ emissions (tonnes) [32], nitrogen oxides $\mathrm{NO}_{\mathrm{x}}$ emissions (tonnes) [33], sulphur oxides $\mathrm{SO}_{\mathrm{x}}$ emissions (tonnes) [34], emissions of non-methane volatile organic compounds (NMVOC) (tonnes) [35], methane $\mathrm{CH}_{4}$ emissions (tonnes) [36], generation of waste (tonnes) [37], annual freshwater withdrawals (total $\mathrm{m}^{3}$ ) [38] as environmental resources; number of employed persons (aged 15-74) [39, 40, 41] and number of work accidents (total, severity 4 days or over) [42] as social resources.

(4) Which return? In this study author uses Gross Domestic Product (GDP) based on purchasingpower-parity (PPP) valuation of country GDP converted into current international dollars as the return figure [43]. This corresponds to the products and services produced by economic entities of the respective country and helps to avoid inflation and different purchasing power across these countries.

(5) Which period? Data used in the calculation of SV is regarding the year 2014. All necessary data were available up to this year at the moment of preparing this research.

(6) Which data sources? Data sources for the analysis were publicly available databases. GDP data was taken from International Monetary Fund as the most reliable economic and financial statistical data. Environmental resources' use data was taken from Eurostat and World Bank. Economic and social resources' use data was taken from the National Statistical Committees of Latvia, Lithuania and Estonia and from Eurostat.

SV can be calculated in five steps [27, 28, 44]:

a) Defining resource efficiencies for countries. Resource efficiencies can be calculated using (1):

$$
e_{i j}^{t}=\frac{G D P_{j}^{t}}{u_{i j}^{t}}
$$

where $e_{i j}^{t}$ - efficiency of the resource $i$ use in country $j$ in year $t ; G D P_{j}^{t}-$ GDP of the country $j$ in year $t ; u_{i j}^{t}$ - the resource $i$ use of the country $j$ in year $t$.

b) Determining benchmark resource efficiencies. The average resource efficiencies in the region are used as the benchmark. In this regard the benchmark 
efficiency of resource $i$ use in year $t\left(e b_{i}^{t}\right)$ can be determined by (2):

$$
e b_{i}^{t}=\sum_{j} \frac{G D P_{j}^{t}}{u_{i j}^{t}}
$$

c) Calculating opportunity costs. Opportunity costs show how much return would be created, if the resources were used not by the country economy, but by the benchmark. Opportunity costs for resource $i$ of the country $j$ in year $t\left(o c_{i j}^{t}\right)$ can be calculated using (3):

$$
o c_{i j}^{t}=e b_{i}^{t} \times u_{i j}^{t}
$$

d) Determining value contributions. On the basis of opportunity costs and GDP of each country can calculate the contribution of each resource in $\mathrm{SV}$ in each year using (4):

$$
C_{i j}^{t}=G D P_{j}^{t}-o c_{i j}^{t}
$$

where $C_{i j}^{t}$ - the contribution of resource $i$ to $\mathrm{SV}$ of country $j$ in year $t$.

e) Defining $S V$. This indicator is calculated using (5) formula as an average of all contributions for a specific country:

$$
S V_{j}^{t}=\frac{\sum_{i} C_{i j}^{t}}{n}
$$

where $S V_{j}^{t}-\mathrm{SV}$ of the country $j$ in year $t ; n-$ the quantity of resources considered.

SV like GDP itself depends on the size of economy. In order to compare different countries the size of a country's economy should be taken into account [45]. Figge and Hahn (2005) suggest using the Return to Cost Ratio (RCR) that expresses how much more efficiently than the benchmark a country uses its resources [46]. RCR puts the country's return in relation to the return the benchmark would have created with the same set of resources (opportunity costs). It can be calculated by the (6):

$$
R C R_{j}^{t}=\frac{G D P_{j}^{t}}{G D P_{j}^{t}-S V_{j}^{t}}
$$

where $R C R_{j}^{t}-$ the RCR for the country $j$ in year $t$.

RCR > 1 indicates that the country yields more efficiently than the benchmark region on average. RCR $<1$ indicates that the country yields less efficiently than the benchmark region on average. Countries create SV when they use their set of resources more efficiently than a benchmark [28, 46].

\section{RESULTS AND DISCUSSION}

This section analyzes the sustainable performance of Latvia, Lithuania and Estonia in 2014 using the SV methodology described above. The performance of each country was compared to a benchmark. The benchmark determines opportunity costs and plays therefore a crucial role. Benchmark reflects the average efficiency of the entire region.
Table1 summarizes the selected economic, social and environmental indicators' values, as well it includes the calculated common SV and RCR for the countries, as well as calculated RCR according to each resource consumed.

As we can see in the Table 1, positive SV is for Latvia and Lithuania, both countries have RCR value 1.41 and 1.32 respectively, which means, that both Latvia and Lithuania use resources more efficiently than the benchmark, i.e. efficiency of resource use is higher than average efficiency of three countries. The same can't be said about Estonia, having negative indicator of SV and value of RCR 0.52, which is less than 1, indicating that Estonia uses resources less efficiently than the benchmark.

Analyzing the efficiency of the each used resource among the three countries, it can be concluded that relatively high score of Latvia is achieved by using several resources more efficiently than the benchmark region on average, for example, the use of the sulphur oxides $\left(\mathrm{SO}_{\mathrm{x}}\right)$ emissions resource is six times effective than the benchmark region on average with $\mathrm{RCR}=6.63$, as well as the use of the resource generation of waste and annual freshwater withdrawal is 3 times effective than the benchmark region on average with $\mathrm{RCR}=3.42$ and $\mathrm{RCR}=3.10$ respectively. In Lithuania, the most efficient resource use is generation of waste with $\mathrm{RCR}=2.39$, but in Estonia - NMVOC emissions with $\mathrm{RCR}=1.56$. All these used resources belong to environmental dimension of sustainable development.

Analyzing the used resource with $\mathrm{RCR}<1$, it can be concluded that, despite the lower results of RCR = 1.32 , nearly all resources are used more efficiently in Lithuania, because it has only one value RCR $<1$ out of the ten of analysed resources, i.e. methane emissions $\left(\mathrm{CH}_{4}\right)$ with $\mathrm{RCR}=0.92$ (environmental dimension of sustainable development).

Latvia, despite reaching the highest value of RCR $=1.41$, uses three out of ten resources less efficiently than the benchmark region on average with $\mathrm{RCR}<1$, they are enterprises' assets, liabilities and equity with $\mathrm{RCR}=0.97$ (economic dimension of sustainable development) emissions of non-methane volatile organic compounds (NMVOC) with $\mathrm{RCR}=0.88$ (environmental dimension of sustainable development) and number of employed persons with $\mathrm{RCR}=0.94$ (social dimension of sustainable development).

Whereas low RCR $=0.52$ of Estonia is justified by the fact that the majority, respectively, seven out of ten resources are used less efficiently than the benchmark region on average, including enterprises' assets, liabilities and equity with $\mathrm{RCR}=0.67$ (economic dimension of sustainable development), carbon dioxide emissions $\left(\mathrm{CO}_{2}\right)$ with $\mathrm{RCR}=0.48$, nitrogen oxides emissions $\left(\mathrm{NO}_{\mathrm{x}}\right)$ with $\mathrm{RCR}=0.78$, sulfur oxides emissions $\left(\mathrm{SO}_{\mathrm{x}}\right)$ with $\mathrm{RCR}=0.31$, generation of waste with $\mathrm{RCR}=0.31$ and annual 
freshwater withdrawal with $\mathrm{RCR}=0,34$ (all of them belong the environmental dimension of the sustainable development) and number of work accidents with $\mathrm{RCR}=0.39$ (social dimension of sustainable development).

Table I

All indicators data and calculation results of SV and RCR for Latvia, Lithuania and Estonia

\begin{tabular}{|c|c|c|c|c|c|c|}
\hline Indicator/Country & Latvia & $\begin{array}{l}\text { RCR of } \\
\text { resource } \\
\text { using }\end{array}$ & Lithuania & $\begin{array}{l}\text { RCR of } \\
\text { resource } \\
\text { using }\end{array}$ & Estonia & $\begin{array}{l}\text { RCR of } \\
\text { resource } \\
\text { using }\end{array}$ \\
\hline $\begin{array}{l}\text { GDP based on PPP valuation of } \\
\text { country GDP } \\
\text { international dollar) }\end{array}$ & 48362000000 & - & 79933000000 & - & 36784000000 & - \\
\hline $\begin{array}{l}\text { Enterprises' assets, liabilities and } \\
\text { equity (total, at the end of the } \\
\text { year, EUR) }\end{array}$ & 56506900000 & 0,97 & 67947179000 & 1,33 & 62643109200 & 0,67 \\
\hline $\mathrm{CO}_{2}$ emissions (tonnes) & 66670663 & 1,76 & 14853526 & 1,31 & 18539395 & 0,48 \\
\hline $\mathrm{NO}_{\mathrm{X}}$ emissions (tonnes) & 37968 & 1,10 & 63554 & 1,08 & 40783 & 0,78 \\
\hline $\mathrm{SO}_{\mathrm{X}}$ emissions (tonnes) & 2723 & 6,63 & 14948 & 1,99 & 43917 & 0,31 \\
\hline NMVOC emissions (tonnes) & 33743 & 0,88 & 53392 & 0,92 & 14488 & 1,56 \\
\hline $\mathrm{CH}_{4}$ emissions (tonnes) & 78510 & 0,93 & 131732 & 0,92 & 39256 & 1,42 \\
\hline Generation of waste (tonnes) & 2621495 & 3,42 & 6200450 & 2,39 & 21804040 & 0,31 \\
\hline $\begin{array}{l}\text { Annual freshwater withdrawals } \\
\text { (total, cubic metres) }\end{array}$ & 248000000 & 3,10 & 631000000 & 2,01 & 1742000000 & 0,34 \\
\hline $\begin{array}{l}\text { Number of employed persons } \\
\text { (aged 15-74) }\end{array}$ & 884600 & 0,94 & 1319000 & 1,04 & 624800 & 1,01 \\
\hline $\begin{array}{l}\text { Number of work accidents (total, } \\
\text { severity } 4 \text { days or over) }\end{array}$ & 1725 & 1,89 & 3120 & 1,73 & 6288 & 0,39 \\
\hline Sustainable Value of a country & \multicolumn{2}{|c|}{14121918755,12} & \multicolumn{2}{|c|}{19408305382,67} & \multicolumn{2}{|c|}{$-33530224137,80$} \\
\hline Return to Cost Ratio of a country & \multicolumn{2}{|l|}{$1, \mathbf{4 1}$} & \multicolumn{2}{|l|}{$1, \mathbf{1 , 3 2}$} & \multicolumn{2}{|l|}{$0, \mathbf{0 , 5 2}$} \\
\hline
\end{tabular}

very high waste intensity as local energy source oil

The obtained data suggests that the primary role of sustainable performance for Latvia, Lithuania and Estonia is a direct environmental dimension for sustainable development. It can be also based on the fact that the environmental dimension indicators are the one which are in the majority in this analysis. Due to the limited volume of the article, the author will focus further on the environmental dimension impact on the sustainable development of Latvia, Lithuania and Estonia.

Significantly low result of Estonia is justified by the relatively high national energy independence if compared to the situation in Latvia and Lithuania. Still in the 1990's energy dependence ${ }^{1}$ was considerable in the tree countries: the total energy dependence was around $45 \%$ for Estonia, $70 \%$ for Lithuania and $90 \%$ for Latvia [47]. Estonia was only about $45 \%$ dependent on foreign energy supply in 1990, because it relied mainly on local resources - oil shale, wood and peat. The reserves of these local resources, especially oil shale, have been large enough to supply the country's energy needs [48].

In 2014, Estonia's gross inland energy consumption consisted of $66.9 \%$ solid fuels, $16.4 \%$ crude oil and petroleum products, $12.8 \%$ renewables and $6.5 \%$ natural gas (author's calculation is based on [49]). Estonia distinguishes from other analysed countries with high diversification of energy mix and

\footnotetext{
${ }^{1}$ Energy dependency shows the extent to which an economy relies upon imports in order to meet its energy needs. The indicator is calculated as net imports divided by the sum of gross inland energy consumption plus bunkers.
}

shale has very high ash content. It uses its oil shale reserves for the production of electricity and to less extent heat. According to a report published by the European Commission in $201186.1 \%$ of Estonia's electricity was produced form oil shale [50]. The production of electricity from burning oil shale generates high levels of $\mathrm{CO}_{2}, \mathrm{SO}_{2}$ and $\mathrm{NO}_{\mathrm{x}}$ emissions [51].

Despite the fact that over the past 25 years, Estonia has decreased the emissions of $\mathrm{SO}_{2}$ and $\mathrm{NO}_{x}$ significantly mainly because of decreased consumption of electricity, the power stations in Estonia have renovated some energy blocks, which has significantly reduced the oil shale consumption and $\mathrm{SO}_{2}$ emissions, however in industrial towns of North-East Estonia (the location of oil shale chemical plants) the level of pollution does not comply with the stricter environmental standards on emissions set out in the EU [51, 52]. The most important measure to reduce oil shale mining is increasing the efficiency of energy production and consumption. Oil shale mining can be reduced by modernising the existing production facilities and bringing them into compliance with environmental requirements, as well as by introducing renewable and other alternative energy source [52].

The record amount generation of waste ${ }^{2}$ for Europe in Estonia also directly depends on the specialization in the production of energy; more than $80 \%$ of all waste is generated by the industrial sector,

\footnotetext{
${ }^{2}$ Estonia generates an average of 16 tonnes of waste per capita (including industrial waste) each year [52].
} 
with $76 \%$ of total waste comprising waste generated by the oil shale industry and energy sector. The major part of hazardous waste (approx. 98\%) is generated by the oil shale and energy sectors. While large amounts of waste indicate that natural resources are not used efficiently, the harmfulness and toxicity of waste reflects its impact on the environment and human health [52]

In 2014 Latvia's gross inland energy consumption consisted of $36.2 \%$ renewables - the highest renewable energy share (RES) in the EU-28, 24.3\% natural gas, $32.2 \%$ crude oil and petroleum products and $1.3 \%$ solid fuels (author's calculation is based on [49]). In 2011 RES has a dominant share in the country's gross electricity generation $-54.9 \%$, mainly being generated by hydro power plants. The other half of electricity is being generated by natural gas $45.1 \%$ [50].

Lithuania was quite independent until the closure of its Nuclear Power Plant in 2009 due to European safety standards (Lithuania had to close Chernobyl type reactor). Now Lithuania has to import most of its energy needs [47]. Lithuanian gross inland consumption in 2014 consisted mainly of natural gas and oil products (30.8\% and $36.5 \%$ respectively), renewable $19.1 \%$ and solid fuels $3.5 \%$ (author's calculation is based on [49]).

Therefore author can conclude that Latvia and Lithuania, in order to promote its economic growth, use mostly energy sources, which are safe to environment, therefore there is lower economic growth burden on the environment in these countries and this is the main factor which ensures that the calculated SV for Latvia and Lithuania is higher.

\section{CONCLUSION}

In the second half of the XX century, along with the world's common growth of IKP, the question regarding the connection between the economic growth and sustainable development became essential. The economic growth is based on the increase of the total consumption, which activates the overall supply and thereby accelerates the rate of economic growth, which results as material well-being of people, under the condition that country carries out fair socioeconomic policy. However, the economic growth brings along the use of financial (or economic), social and natural resources. And sometimes the use of these resources is not properly considered and is ineffective, which means that such economic growth is a threat to the sustainable development of the country.

The sustainable development is being defined as "development that meets the needs of the present without compromising the ability of future generations to meet their own needs". This means that we have to take into a consideration the fact that we didn't inherit the Earth from our ancestors, but borrowed it from our children. Therefore, the integration of the three dimensions of sustainable development is not merely an aspiration, it is vital for the survival of societies, ecosystems and economies.

The research analyses the Sustainable Value of Latvia, Lithuania and Estonia, revealing the value that is created or lost through the use of a set of different resources by a country, making a comparison to the benchmark. The average efficiency of Latvia, Lithuania and Estonia as the benchmark was applied in this research. The resources for the calculation were chosen according to economic, social and environmental dimensions of sustainable development. The results of the calculation revealed the fact that among three countries, Latvia and Lithuania has positive SV and RCR indicator is $>1$, which means that both Latvia and Lithuania use resources more efficiently than the benchmark, i.e. efficiency of the use of the resources is higher than average efficiency of three countries. Whereas SV indicator of the Estonia is negative and RCR value is $<1$, which means that Estonia uses resources less efficiently than the benchmark. The result of Estonia differs because of the fact that among the three countries Estonia is the most energy-independent, although this independence is based on the oil shale extraction and the use of it for producing electricity, which is harmful to the environment and significantly pollutes the environment.

Therefore the author concludes that the relatively higher socio-economic development of Estonia is achieved by exhaustion of the natural resources and is on the contrary to the world's sustainable development prerequisites.

\section{REFERENCES}

[1] S. Jahan, Human Development Report 2015. Work for Human Development. United Nation Development Programme, 2015.

[2] K. Schwab and X. Sala-i-Martin, The Global Competitiveness Report 2016-2017. World Economic Forum, 2016.

[3] Doing Business 2017. Equal Opportunity for All. International Bank for Reconstruction and Development / The World Bank, 2016.

[4] F. Figge, "Environmental Value Added - a New Approach to Measuring Eco-Efficiency", Z. Angew. Umweltforsch, 14, pp.184-197, 2001.

[5] F Figge and T. Hahn, "Sustainable value added - measuring corporate contributions to sustainability beyond ecoefficiency," Ecological Economics, 48, pp.173-187, 2004.

[6] S. Manzhynski, N. Siniak, A. Zróbek-Rózanska, S. Zróbek, "Sustainability performance in the Baltic Sea Region", Land Use Policy, 57, pp.489-498, 2016.

[7] D. H. Meadows, D. L. Meadows, J. Randers, W. W. Behrens III, The Limits to Growth. A Report for the Club of Rome's Project on the Predicament of Mankind. New York: Universe Books, 1972.

[8] L. Fei, S. Dong, L. Xue, L. Q. Liang, W. Yang, "Energy consumption-economic growth relationship and carbon dioxide emissions in China," Energy Policy, Volume 39, Issue 2, pp. 568-574, 2011.

[9] K. Alkhathlan and M. Javid, "Energy consumption, carbon emissions and economic growth in Saudi Arabia: an aggregate and disaggregate analysis," Energy Policy, Volume 62, pp.1525-1532, 2013.

[10] E. A. Rosa and A. Diekmann, T. Dietz, C. Jaeger, Human Footprints on the Global Environment: Threats to Sustainability. London: The MIT Press, 2010. 
[11] A. K. Jorgenson, "Carbon Dioxide Emissions in Central and Eastern European Nations, 1992-2005: A Test of Ecologically Unequal Exchange Theory," Human Ecology, Rev. 18, pp. 105-114, 2011.

[12] A. Jorgenson and B. Clark, V. Giedraitis, "The temporal (in)stability of the carbon dioxide emissions/economic development relationship in Central and Eastern European nations," Society and Natural Resources, Vol. 25, pp.1182$1192,2012$.

[13] A. Jorgenson and B. Clark, "Societies consuming nature: a panel study of the ecological footprints of nations 19602003," Social Science Research, Vol. 40, pp. 226-244, 2011.

[14] P. Knox, J. Agnew, L. McCarthy, The Geography of the World Economy, $6^{\text {th }}$ edition. London: Routledge, 2014.

[15] World Commission on Environment and Development, Our Common Future (The Brundtland Report). Oxford /New York: Oxford University Press, 1987. [Online]. Available: www.un-documents.net/our-common-future.pdf. [Accessed: December 15, 2016].

[16] Transforming our world: the 2030 Agenda for Sustainable Development, United Nations General Assembly, 21 October 2015. [Online]. Available: http://www.un.org/ga/ search/view_doc.asp?symbol=A/RES/70/1\&Lang=E. [Accessed: December 15, 2016].

[17] Science for Environment Policy, Indicators for Sustainable Cities, in-depth Report 12. Produced for the European Commission DG Environment by the Science Communication Unit, UWE, Bristol, 2015. [Online]. Available:

http://ec.europa.eu/environment/integration/research/newsale rt/pdf/indicators_for_sustainable_cities_IR12_en.pdf.

[Accessed: January 7, 2017].

[18] Forum for the Future, The Five Capitals, 2016. [Online] Available: https://www.forumforthefuture.org/project/fivecapitals/overview. [Accessed: January 7, 2017].

[19] N. R. Goodwin, Five Kinds of Capital: Useful Concepts for Sustainable Development. Global Development and Environment Institute, Working Paper No. 03-07, 2003. [Online]. Available: http://www.ase.tufts.edu/gdae/ publications/working_papers/0307sustainabledevelopment.pdf. [Accessed: January 7, 2017].

[20] J. Birkeland, Positive Development: From Vicious Circles to Virtuous Cycles Through Built Environment Design. Earthscan Ltd., 2008.

[21] T. Everett, M. Ishwaran, G. P. Ansaloni, A. Rubin, Economic Growth and the Environment. Defra Evidence and Analysis Series. Paper 2, Department for Environment Food and Rural Affairs, 2010. [Online]. Available: https://www.gov.uk/ government/uploads/system/uploads/attachment_data/file/69 195/pb13390-economic-growth-100305.pdf. [Accessed: January 7, 2017].

[22] P. Ekins, Economic Growth and Environmental Sustainability: The Prospects for Green Growth. London: Routledge, 2000

[23] K. Scott, J. Barrett, G. Baiocchi, J. Minx, Meeting the UK climate change challenge: The contribution of resource efficiency. WRAP Project EVA128. Report prepared by Stockholm Environment Institute and University of Durham Business School, Waste \& Resources Action Programme, 2009. [Online]. Available: http://www.wrap.org.uk/sites/ files/wrap/Final\%20Report\%20EVA128_SEI\%20(1)\%20JB $\% 20$ SC\%20JB3.pdf. [Accessed: January 7, 2017].

[24] T. Hahn, F. Figge, R. Barkemeyer, "Sustainable value creation among companies in the manufacturing sector," International Journal of Environmental Technology and Management, 8, pp. 496-512, 2007.

[25] T. Hahn, F. Figge, R. Barkemeyer, A. Liesen, F. Müller, Sustainable Value in Automobile Manufacturing: an Analysis of the Sustainability Performance of the Automobile Manufacturers Worldwide, 3rd ed. Sustainable Value Ltd., 2013. [Online]. Available: http://sustainablevalue.com/ downloads/sustainablevalueinautomobilemanufacturing3rded .pdf . [Accessed: December 15, 2016].
[26] F. Ang, S. Van Passel, E. Mathijs, "An aggregate resource efficiency perspective on sustainability: a sustainable value application to the EU-15 countries," Ecological Economics, 71, pp. 99-110, 2011.

[27] S. Manzhynski, F. Figge, L. Hassel, "Sustainable Value creation of nine countries of the Baltic region. Value, changes and drivers," Journal of Cleaner Production, 108, pp. 637-646, 2015.

[28] Sustainable Value of European Industry: A Value-Based Analysis of the Environmental Performance of European Manufacturing Companies. Full Version. The ADVANCE project, 2006. [Online]. Available: http://www.advanceproject.org/downloads/advancesurveyfullversion.pdf.

[Accessed: December 15, 2016].

[29] Latvijas Republikas Centrālās Statistikas pārvalde, Komersantu (komercsabiedrību) finansiālie rādītäji gada beigās, UFG01, 2014. [Online]. Available: http://data.csb.gov.lv/pxweb/lv/ekfin/ekfin_ikgad_uznemfi n/UF0010_euro.px/?rxid=cdcb978c-22b0-416a-aaccaa650d3e2ce0. [Accessed: December 15, 2016].

[30] Lietuvos statistikos departamentas, Total assets of enterprises, 2014. [Online]. Available: http://osp.stat.gov.lt/ en/statistiniu-rodikliu-

analize?portletFormName $=$ visualization $\&$ hash $=96 \mathrm{c} 74 \mathrm{c} 44-$ 6ee9-40cb-9306-5461b5c37c5b. [Accessed: December 15, 2016].

[31] Statistics Estonia, Enterprises' assets, liabilities and equity by economic activity (EMTAK 2008) and number of persons employed, FS009, 2014. [Online]. Available: http://pub.stat.ee/px-

web.2001/Dialog/varval.asp?ma=FS009\&ti=ENTERPRISES $\% 27+$ ASSETS $\% 2 \mathrm{C}+$ LIABILITIES+AND+EQUITY+BY+E CONOMIC+ACTIVITY+\%28EMTAK+2008\%29+AND+N UMBER+OF+PERSONS+EMPLOYED\&path=../I_Databas/ Economy/09Financial_statistics_of_enterprises/02Enterprises _assets/02Annual_statistics/\&lang=1. [Accessed: December 15, 2016].

[32] Eurostat, Air emissions accounts by NACE Rev. 2 activity. Carbon dioxide, 2014. [Online]. Available: http://appsso.eurostat.ec.europa.eu/nui/submitViewTableActi on.do. [Accessed: December 15, 2016].

[33] Eurostat, Air emissions accounts by NACE Rev. 2 activity. Nitrogen oxides, 2014. [Online]. Available: http://appsso.eurostat.ec.europa.eu/nui/submitViewTableActi on.do. [Accessed: December 15, 2016].

[34] Eurostat, Air emissions accounts by NACE Rev. 2 activity. Sulphur oxides, 2014. [Online]. Available: http://appsso.eurostat.ec.europa.eu/nui/submitViewTableActi on.do. [Accessed: December 15, 2016].

[35] Eurostat, Air emissions accounts by NACE Rev. 2 activity. Non-methane volatile organic compounds, 2014. [Online]. Available:

http://appsso.eurostat.ec.europa.eu/nui/submitViewTableActi on.do. [Accessed: December 15, 2016].

[36] Eurostat, Air emissions accounts by NACE Rev. 2 activity. Methane, 2014. [Online]. Available: http://appsso.eurostat.ec. europa.eu/nui/submitViewTableAction.do. [Accessed: December 15, 2016].

[37] Eurostat, Generation of waste by waste category, 2014. [Online]. Available: http://ec.europa.eu/eurostat/ tgm/table.do?tab=table\&init=1\&plugin $=1 \&$ pcode $=\operatorname{ten} 00108$ \&language $=$ en. [Accessed: December 15, 2016].

[38] World Bank. Annual freshwater withdrawals, total (billion cubic meters), 2014. [Online]. Available: http://data.worldbank.org/indicator/ER.H2O.FWTL.K3. [Accessed: December 15, 2016]

[39] Latvijas Republikas Centrālās Statistikas pārvalde, Nodarbinātie pa vecuma grupām un pēc dzimuma, NBG07, 2014. [Online]. Available: http://data.csb.gov.lv/ pxweb/lv/Sociala/Sociala_ikgad_nodarb/NB0070.px/?rxid $=\mathrm{cdcb} 978 \mathrm{c}-22 \mathrm{~b} 0-416 \mathrm{a}-\mathrm{aacc}-\mathrm{aa} 650 \mathrm{~d} 3 \mathrm{e} 2 \mathrm{ce} 0$. [Accessed: December 15, 2016].

[40] Lietuvos statistikos departamentas, Employed persons, 2014. [Online]. Available: http://osp.stat.gov.lt/web/guest/ 
statistiniu-rodikliu-analize?portletFormName=visualization \& hash $=34 b 4 b 212-89 c f-4844-b 4 f 0-16 a 2864$ eec68. [Accessed: December 15, 2016]

[41] Statistics Estonia, Employed persons by full/part-time job in main job, ML220, 2014. [Online]. Available: http://www.stat.ee/37204?highlight=employed,persons. [Accessed: December 15, 2016].

[42] Eurostat, Accidents at work by sex, age, severity, NACE Rev. 2 activity and workstation, 2014. [Online]. Available: http://appsso.eurostat.ec.europa.eu/nui/submitViewTableActi on.do. [Accessed: December 15, 2016].

[43] International Monetary Fund, Gross domestic product based on purchasing-power-parity $(P P P)$ valuation of country $G D P, 2014 . \quad$ [Online]. Available: http://www.imf.org/ external/pubs/ft/weo/2015/02/weodata/weorept.aspx?sy=201 $3 \&$ ey $=2020 \& \mathrm{scsm}=1 \& \mathrm{ssd}=1 \&$ sort $=$ country $\& \mathrm{ds}=. \& \mathrm{br}=1 \& \mathrm{pr}$ 1. $\mathrm{x}=84 \& \mathrm{pr} 1 . \mathrm{y}=8 \& \mathrm{c}=946 \% 2 \mathrm{C} 939 \% 2 \mathrm{C} 941 \& \mathrm{~s}=\mathrm{NGDPD} \% 2 \mathrm{CP}$ PPGDP\%2CLE\&grp=0\&a=\#download. [Accessed: December 15, 2016].

[44] A. Liesen, F. Müller, F. Figge, T. Hahn, Sustainable Value Creation by Chemical Companies. Sustainable Value Research, 2009. [Online]. Available: http://www.sustainablevalue.com/downloads/sustainablevalu ecreationbychemicalcompanies.pdf. [Accessed: December 15, 2016].

[45] R. J. Baumgartner, "Corporate sustainability performance: methods and illustrative example," The International Journal of Sustainable Development and Planning, 3 (2), pp. 117 $131,2008$.

[46] F. Figge, T. Hahn, "The cost of sustainability capital and the creation of sustainable value by companies," Journal of Industrial Ecology, 9 (4), pp. 47-58, 2005.
[47] T. J. Weyers, Energy Security of the Baltic States. Bachelor Thesis, 2013. [Online]. Available: https://repositori.upf.edu/ handle/10230/21000. [Accessed: January 7, 2017].

[48] A. Mae, "Estonian Energy Strategy and its implications to the Regional Cooperation," In: A.Spruds and T.Rostoks, eds. 2009. Energy: Pulling the Baltic Sea Region Together or Apart? Riga: Latvian Institute of International Affairs, pp.250-282, 2009.

[49] Eurostat, Gross inland energy consumption by fuel type, 2014. [Online]. Available: http://ec.europa.eu/eurostat/ tgm/refreshTableAction.do?tab $=$ table \&plugin $=1 \&$ pcode $=$ tsdc c320\&language $=e n$. [Accessed: January 7, 2017].

[50] European Commission, Energy Markets in the European Union in 2011. Luxembourg: Publications Office of the European Union, 2012. [Online]. Available: http://bookshop. europa.eu/en/energy-markets-in-the-european-union-in-2011pbMJAE12001/. [Accessed: January 7, 2017].

[51] M. Maigre, Energy Security Concerns of the Baltic States. International Centre for Defence Studies, 2010. [Online]. Available: https://www.icds.ee/fileadmin/media/icds.ee/ failid/Merle_Maigre-Energy_Security_Concers_of_the Baltic_States.pdf. [Accessed: January 7, 2017].

[52] M. Saul, K. Antso, Estonian environmental indicators development and outcomes. Estonian Environment Agency, 2014. [Online]. Available: http://www.keskkonnainfo.ee/ failid/indikaatorid_ENG_web.pdf. [Accessed: January 7, 2017]. 